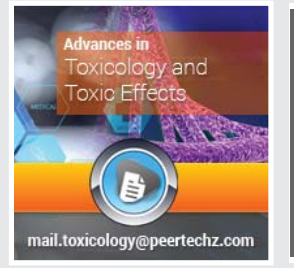

\section{Infertility among iron industry}

\section{workers}

\section{Zorawar Singh*}

Department of Zoology, Khalsa College, Amritsar 143001, Punjab, India
Received: 05 February, 2020

Accepted: 18 March, 2020

Published: 19 March, 2020

*Corresponding author: Dr. Zorawar Singh, Assistant Professor, Department of Zoology, Khalsa College, Amritsar 143001, Punjab, India, Tel: +91-9417230075, E-mail: zorawarsinghs@rediffmail.com

Keywords: Infertility; Occupational exposure; Industry; Chemicals; Factory workers

https://www.peertechz.com

\title{
Abstract
}

Occupational exposures in different industries may pose serious health impacts. A number of epidemiological studies have focused on the association of occupational exposures and adverse health effects. The need of the hour is to focus on the reproductive health of workers engaged at different jobs in varied industries. Increasing environmental as well as occupational exposures have led to serious effects on the reproductive health of workers and have also endangered the life of future generations. The present paper highlights the impact of occupational exposures on iron industry workers. Future health based researches are recommended so as to assess the impact of occupational exposures on reproductive capabilities of workers.

Occupational exposures can be the major cause of infertility. Iron industry has previously been assessed for different associated toxicities [1-5]. A wide range of studies have been conducted to assess the effects of occupations on the fertility status of workers [6-11]. Different industries involve an exposure to different sets of chemicals, nascent metals, dusts and fumes. Iron industries involve different industrial operations like welding, cutting, grinding and painting. Welding fumes may have a number of different metals including Chromium (Cr); Copper (Cu); Nickel (Ni); Manganese $(\mathrm{Mn})$; and Iron $(\mathrm{Fe})$. In one of the study, the incidence of trace metals in human seminal plasma and possible correlations between levels of toxic metals and semen quality was investigated; $\mathrm{Cd}$ and $\mathrm{Ni}$ were found to show significant difference $(p<0.05)$ among three monitored groups of normozoospermia, oligozoospermia and azoospermia [12]. In another study, endometrial concentrations of heavy metals including cadmium, lead, mercury and arsenic were investigated; and cadmium was suggested to act as a contributing factor in the etiology of unexplained infertility among 33 women subjects [13].

Cadmium can directly affect the testes. A testicular toxin and various derived compounds were shown to induce severe damage to the spermatogenic epithelium in animal models. Cadmium effect on the testes appears to be manifested mainly in the sertoli cells, which has been proved by scanning electron microscopy as increasing morphological changes.
Thus toxic metals have been found to be causative agents in infertility among different populations [14-17]. Semen quality is a parameter which also affects the reproduction. Semen quality has been extensively investigated among the welders by different researchers [18-24]. Semen quality of 57 workers from a welding plant and 57 controls was monitored and sperm concentrations of exposed workers were found to be $14.5 \pm 24.0 \mathrm{million} / \mathrm{ml}$ as compared to control group $(62.8 \pm 43.7$ million/ml). Rapid linear sperm motility was found to be decreased in exposed workers as compared to controls and a significant positive correlation between the percentage of sperm tail defects and blood nickel concentration in exposed workers. On the other hand, sperm concentration showed a negative correlation with blood chromium content in workers [18]. Similarly, low-level exposure to hexavalent chromium associated with TIG stainless steel and mild steel welding was not found to be a major hazard for human spermatogenesis [21]. Chromium-induced reproductive toxicity was suggested to be through oxidative stress. In an another study, the distribution and temporal variability of power-frequency magnetic field exposure in men, and the correlation of exposures within couples using data from a longitudinal study of 25 men and their female partners recruited from an infertility clinic was conducted. The average and $90^{\text {th }}$ percentile demonstrated fair to good reproducibility, whereas the maximum poor reproducibility was shown over repeated sampling days, each separated by a median of 4.6weeks [9]. 


\section{Conclusion}

Iron industry is employing a huge number of workers to meet its requirements. Workers of these industries are exposed to different sets of chemicals and physical factors after which they may suffer from various reproductive health ailments. Studies reveal a substantial decrease in the sperm count among exposed workers $(14.5 \pm 24.0 \mathrm{million} / \mathrm{ml})$ as compared to control group $(62.8 \pm 43.7$ million $/ \mathrm{ml})$. As a precautionary measure, workers should be provided proper protection equipments so as to minimize the exposure during different industrial processes. Workers should also be checked regularly for their different health parameters including reproductive health.

\section{References}

1. Singh Z, Chadha P (2014) DNA Damage Due to Inhalation of Complex Metal Particulates among Foundry Workers. Adv Env Biol 8: 225-230. Link: https://bit.ly/2UceyPc

2. Singh Z, Chadha P, Sharma S (2016) Lung Health among Welders. American J Env Occu Health 1: 6-10. Link: https://bit.ly/2WIHvuM

3. Singh Z, Chadha P (2012) Health Concerns in Welding Industry. Int J Enh Res Sci Tech Eng 2: 1-5. Link: https://bit.ly/2Wpl4oG

4. Singh Z, Chadha P (2013) Oxidative Stress Assessment among Iron Industry Grinders. Biochem Cell Arch 13: 65-68. Link: https://bit.ly/2xOXhnJ

5. Singh Z, Chadha P (2016) Assessment of DNA Damage as an Index of Genetic Toxicity in Welding Micro-environments among Iron Based Industries. Tox Ind Health 32: 1817-1824. Link: https://bit.ly/2IXWJ1b

6. Chia SE, Lim ST, Tay SK, Lim ST (2000) Factors associated with male infertility: a case-control study of 218 infertile and 240 fertile men. BJOG 107: 55-61. Link: https://bit.ly/2UjwPu3

7. Chia SE, Tay SK (2001) Occupational risk for male infertility: a case-contro study of 218 infertile and 227 fertile men. J Occup Environ Med 43: 946-951. Link: https://bit.ly/3b4FTcR

8. Claman P (2004) Men at risk: occupation and male infertility. Fertil Steril 81 19-26. Link: https://bit.ly/2IU5M2W

9. Lewis RC, Hauser R, Maynard AD, Neitzel RL, Wang L, et al. (2016) Personal measures of power frequency magnetic field exposure among men from an infertility clinic: distribution, temporal variability and correlation with their female partener's exposure. Radiat Prot Dosimetry 172: 401-408. Link: https://bit.ly/38WJwQz

10. Melgarejo $M$, Mendiola J, Koch HM, Monino-Garcia M, Noguera-Velasco $\mathrm{JA}$, et al. (2015) Associations between urinary organophosphate pesticide metabolite levels and reproductive parameters in men from an infertility clinic. Environ Res 137: 292-298. Link: https://bit.ly/3b70QU

11. Tsujimura A, Matsumiya K, Takahashi T, Yamanaka M, Koga M, et al. (2004) Effect of lifestyle factors on infertility in men. Arch Androl 50: 15-17. Link: https://bit.ly/33sm9gC

12. Zafar A, Eqani SA, Bostan N, Cincinelli A, Tahir F, et al. (2015) Toxic metals signature in the human seminal plasma of Pakistani population and their potential role in male infertility. Environ Geochem Health 37: 515-527. Link: https://bit.ly/2TYqapX
13. Tanrikut E, Karaer A, Celik O, Celik E, Otlu B, et al. (2014) Role of endometria concentrations of heavy metals (cadmium, lead, mercury and arsenic) in the aetiology of unexplained infertility. Eur J Obstet Gynecol Reprod Biol 179: 187 190. Link: https://bit.ly/2QFDgqr

14. Inhorn MC, King L, Nriagu JO, Kobeissi L, Hammoud N, et al. (2008) Occupational and environmental exposures to heavy metals: risk factors for male infertility in Lebanon? Reprod Toxicol 25: 203-212. Link: https://bit.ly/390WfSz

15. Podzimek S, Prochazkova J, Pribylova L, Bartova J, Ulcova-Gallova Z, et al. (2003) Effect of heavy metals on immune reactions in patients with infertility. Cas Lek Cesk 142: 285-288. Link: https://bit.ly/391oBMe

16. Nivsarkar M, Cherian B, Patel S (1998) A regulatory role of sulfhydryl groups in modulation of sperm membrane conformation by heavy metals: sulfhydry groups as markers for infertility assessment. Biochem Biophys Res Commun 247: 716-718. Link: https://bit.ly/2xOVfnB

17. Bonde JP (1993) The risk of male subfecundity attributable to welding of metals. Studies of semen quality, infertility, fertility, adverse pregnancy outcome and childhood malignancy. Int $\mathrm{J}$ Androl 16: 1-29. Link: https://bit.ly/2QrZ20F

18. Danadevi K, Rozati R, Reddy PP, Grover P (2003) Semen quality of Indian welders occupationally exposed to nickel and chromium. Reprod Toxicol 17 451-456. Link: https://bit.ly/2vziCRo

19. Kumar S, Zaidi SS, Gautam AK, Dave LM, Saiyed HN (2003) Semen quality and reproductive hormones among welders -A preliminary study. Environ Health Prev Med 8: 64-67. Link: https://bit.ly/33pfDaG

20. Raymond LW (1993) Semen quality in welders exposed to radiant heat. $\mathrm{Br} J$ Ind Med 50: 1055-1056. Link: https://bit.ly/33tJ4YU

21. Bonde JP, Ernst E (1992) Sex hormones and semen quality in welders exposed to hexavalent chromium. Hum Exp Toxicol 11: 259-263. Link: https://bit.ly/2UeAUzv

22. Bonde JP (1992) Semen quality in welders exposed to radiant heat. $\mathrm{Br} \mathrm{J}$ Ind Med 49: 5-10. Link: https://bit.ly/2TXzGty

23. Bonde JP (1990) Semen quality in welders before and after three weeks of non-exposure. Br J Ind Med 47: 515-518. Link: https://bit.ly/2IY8G78

24. Bonde JP (1990) Semen quality and sex hormones among mild steel and stainless steel welders: a cross sectional study. $\mathrm{Br} \mathrm{J}$ Ind Med 47: 508-514. Link: https://bit.ly/39Zpc2B

\section{Discover a bigger Impact and Visibility of your article publication with} Peertechz Publications

\section{Highlights}

* Signatory publisher of ORCID

* Signatory Publisher of DORA (San Francisco Declaration on Research Assessment)

- Articles archived in worlds' renowned service providers such as Portico, CNKI, AGRIS, TDNet, Base (Bielefeld University Library), CrossRef, Scilit, J-Gate etc

* Journals indexed in ICMJE, SHERPA/ROMEO, Google Scholar etc.

* OAI-PMH (Open Archives Initiative Protocol for Metadata Harvesting)

* Dedicated Editorial Board for every journa

* Accurate and rapid peer-review process

* Increased citations of published articles through promotions

- Reduced timeline for article publication

Submit your articles and experience a new surge in publication services (https://wWw.peertechz.com/submission).

Peertechz journals wishes everlasting success in your every endeavours.

Copyright: ๑) 2020 Singh Z. This is an open-access article distributed under the terms of the Creative Commons Attribution License, which permits unrestricted use, distribution, and reproduction in any medium, provided the original author and source are credited. 